\title{
Correlation between inhibin secretion and damage of seminiferous tubules in a model of experimental autoimmune orchitis
}

\author{
M O Suescun ${ }^{1,2}$, L Lustig ${ }^{3}$, R S Calandra ${ }^{2,4}$, N P Groome ${ }^{5}$ \\ and $\mathbf{S}$ Campo ${ }^{6}$ \\ ${ }^{1}$ Instituto Multidisciplinario de Biología Celular, cc 403, 1900 La Plata, Argentina \\ ${ }^{2}$ Facultad de Ciencias Exactas, UNLP, Calle 47 y 115, 1900 La Plata, Argentina \\ ${ }^{3}$ Centro de Investigaciones en Reproducción, Facultad de Medicina, Universidad de Buenos Aires, Paraguay 2155, Piso 10, 1121 Buenos Aires, Argentina \\ ${ }^{4}$ Instituto de Biología y Medicina Experimental, Vuelta de Obligado 2490, 1428 Buenos Aires, Argentina \\ ${ }^{5}$ Oxford Brookes University, Gipsy Lane Campus, Headington, Oxford OX3 OBP, UK \\ ${ }^{6}$ CEDIE, Hospital de Niños R.Gutiérrez, Gallo 1330, 1425 Buenos Aires, Argentina \\ (Requests for offprints should be addressed to M O Suescun, Instituto Multidisciplinario de Biología Celular, cc 403, 1900 La Plata, Argentina; \\ Email: suescun@nahuel.biol.unlp.edu.ar)
}

\begin{abstract}
The aim of the present study was to evaluate inhibin secretion in rats with autoimmune orchitis. As we have previously described, experimental autoimmune orchitis (EAO) induced in rats by active immunization with testis homogenate and adjuvants is characterized by an interstitial mononuclear cell infiltrate and sloughing of the germinal epithelium. At 120 days after the first immunization $60 \%$ of the rats exhibited a severe orchitis with large areas of aspermatogenic seminiferous tubules in which only spermatogonia and Sertoli cells with cytoplasmic vacuolization remained attached to the tubular wall. None of the untreated $(\mathrm{N})$ or control $(\mathrm{C})$ rats revealed pathological alterations. Sixty percent decrease in testis weight was observed in rats with EAO compared with $\mathrm{N}$ or C groups. A 3-fold increase in serum FSH levels was observed in rats with EAO compared with $\mathrm{N}$ or $\mathrm{C}$ groups $(19.8 \pm 3.7$ vs $5.6 \pm 0.3$ and $5.9 \pm 0.1 \mathrm{ng} / \mathrm{ml}$
\end{abstract}

respectively). A significant decrease in inhibin $\mathrm{B}$ levels was observed in rats with $\mathrm{EAO}$ when compared with $\mathrm{N}$ or $\mathrm{C}$ groups ( $40 \pm 4 \cdot 6$ vs $207 \pm 38 \cdot 8$ and $221 \cdot 4 \pm 28 \cdot 6 \mathrm{pg} / \mathrm{ml}$ respectively). An inverse correlation between inhibin $\mathrm{B}$ and FSH serum levels and a direct correlation between inhibin B and testis weight were found. Strong expression of the inhibin $\alpha$-subunit in Sertoli cells of untreated and control rats was observed; this subunit was undetectable or poorly detectable in rats with orchitis. Positive staining for the inhibin $\alpha$-subunit was also observed in Leydig cells of all groups studied. In conclusion, using a model of autoimmune orchitis our results show that circulating inhibin B levels and inhibin $\alpha$-subunit expression in Sertoli cell cytoplasm closely correlate with the degree of damage of the germinal epithelium.

Journal of Endocrinology (2001) 170, 113-120

\section{Introduction}

Inhibin is a heterodimeric glycoprotein which was initially characterized by its ability to suppress the synthesis and/or secretion of follicle-stimulating hormone (FSH) (de Jong 1988, de Kretser \& McFarlane 1996, Burger \& Robertson 1997). It is composed of $\alpha$ - and $\beta$-subunits. Heterodimerization of $\alpha$-subunit with either form of the $\beta$-subunit $(\beta A$ and $\beta B)$ generates dimeric inhibin $A$ and inhibin $B$ respectively. Specific assays for the measurement of dimeric inhibins have been developed (Groome et al. 1994, 1996). Evidence obtained in both physiological and pathological conditions is consistent with inhibin B being the relevant physiological inhibin form involved in FSH negative feedback in the male (Anawalt et al. 1996, Illingworth et al. 1996, Majundar et al. 1997, Anderson \&
Sharpe 2000). The high correlation between circulating inhibin B levels and sperm concentration in the ejaculate observed in normal and infertile men led to the proposal that inhibin B is a reliable marker of spermatogenesis (Jensen et al. 1997, Pierik et al. 1998).

The immunoactive inhibin found in the male circulation is produced mainly in the testis under the stimulation of FSH secretion (Steinberger \& Steinberger 1976, Bicsack et al. 1987). Within the testis, the Sertoli cell has been proposed as the major source of inhibin B production (Depuydt et al. 1999). The levels of mRNA for the inhibin subunits and the concentration of immunoactive inhibin secreted by seminiferous tubules vary according to the stage of the seminiferous cycle (Merchenthaler et al. 1987, Rivier et al. 1988, Bhasin et al. 1989). More recently this observation was confirmed by Klaij et al. (1994) who 
studied stage-synchronized spermatogenesis induced by vitamin A administration in vitamin A-deficient rats. Based on previous evidence the production of inhibin by the Sertoli cell has been proposed to be under paracrine control by germ cells. In addition, it has been observed that men with impaired spermatogenesis (spermatogenic arrest, Sertoli cell-only syndrome or Klinefelter's syndrome) generally present very low or undetectable serum inhibin B levels (Anawalt et al. 1996). Andersson et al. (1998) proposed that inhibin B is a joint product of Sertoli and germ cells.

Experimental autoimmune orchitis (EAO) is a T-cell mediated disease regulated by local, genetic and immunological factors (Mahi-Brown 1994). We have previously reported (Doncel et al. 1989) that rats immunized with testis homogenate $(\mathrm{TH})$ and adjuvants develop an EAO characterized by an interstitial mononuclear cell infiltrate, damage of the germinal epithelium and aspermatogenesis. Starting on day 80 after the first immunization a severe sloughing of germinal cells begins to occur and seminiferous tubules present spermatogonia, some spermatocytes and Sertoli cells with vacuolization of the cytoplasm. Levels of serum FSH were increased in rats with EAO when compared with those detected in control groups (Suescun et al. 1994).

The aim of the present study was to determine the serum profile of inhibin B as a peripheral marker of Sertoli cell function and to evaluate the testicular cell capability to express the inhibin $\alpha$-subunit in an experimental model characterized by a severe damage of the seminiferous epithelium and impaired testicular cell interactions.

\section{Materials and Methods}

\section{Animals}

Male Sprague-Dawley rats aged 50-56 days (mean weight $270 \mathrm{~g}$ ) were used. Animals were housed at $22{ }^{\circ} \mathrm{C}$ with a $14 \mathrm{~h}$ light:10 h darkness schedule and were fed standard food pellets and water available ad libitum.

\section{Immunization schedule}

Rats of the experimental group (E) were immunized with testicular homogenate $(\mathrm{TH})$ prepared as previously described (Doncel et al. 1989). Briefly, testes harvested from humanely killed rats were decapsulated, placed in an equal volume of physiological saline, and disrupted in an Omni mixer for $30 \mathrm{~s}$. A final concentration of $500 \mathrm{mg} / \mathrm{ml}$ $(\mathrm{w} / \mathrm{w})$ was obtained. Animals were injected three times with $200 \mathrm{mg}(\mathrm{w} / \mathrm{w}) \mathrm{TH}$ per dose, per rat, at 14 day intervals. Antigen $(0.4 \mathrm{ml})$ emulsified with $0.4 \mathrm{ml}$ Freund's complete adjuvant (CFA) was injected intradermally in footpads and at multiple sites near ganglionar regions. The first two immunizations were immediately followed by an i.v. injection of $0.5 \mathrm{ml}$ Bordetella pertussis
(Bp) (strain 10536; Instituto Malbrán, Buenos Aires, Argentina) containing $10^{10}$ micro-organisms. After the third immunization, $5 \times 10^{9}$ micro-organisms were injected i.p. The control (C) group of rats was injected with an emulsion of saline, CFA, and Bp under the same conditions as for the E group. Non-immunized normal rats $(\mathrm{N})$ of the same age as the animals described above were also studied. Rats were killed at 120 days after the first immunization. Both testes were weighed for each rat and one testis from some animals of each group was fixed in Bouin's solution and processed for light microscopy. Blood was collected and sera were stored at $-20{ }^{\circ} \mathrm{C}$ for measurement of serum inhibin $\mathrm{B}$, testosterone, luteinizing hormone (LH) and FSH levels.

\section{Morphological and immunohistochemical techniques}

For light microscopy, testes were fixed in Bouin's solution, embedded in paraffin, sectioned at three different levels and stained with haematoxylin-eosin (HE).

For immunohistochemistry, $5 \mu \mathrm{m}$ thick testis sections mounted on silane-coated slides were dewaxed, rehydrated in graded ethanol, washed in phosphate buffer $0 \cdot 1 \mathrm{M}, \mathrm{pH} 7 \cdot 3$ (PBS). Sections were subjected to antigen retrieval by microwaving in $0.01 \mathrm{M}$ citrate buffer, $\mathrm{pH} 5 \cdot 5$ on full power $(770 \mathrm{~W})$ for $3 \mathrm{~min}$ and on $40 \%$ power for an additional $15 \mathrm{~min}$. Sections were allowed to cool at room temperature, washed in PBS, incubated in $0 \cdot 3 \% \mathrm{H}_{2} \mathrm{O}_{2}$ in methanol to block endogenous peroxidase, washed in PBS and blocked with normal horse serum. Sections were then incubated for $40 \mathrm{~min}$ with a purified mouse monoclonal antibody directed against the inhibin $\alpha$-subunit (Groome et al. 1990), washed and incubated with a horse biotinylated anti-mouse IgG (affinity purified, 'rat adsorbed') (1:50) (Vector Laboratories, Burlingame, CA, USA). After washing in PBS, sections were subsequently incubated with the avidin-biotin-peroxidase complex (Vector Laboratories) and then washed in PBS. Colour was developed with 3,3'-diaminobenzidine tetrahydrochloride (DAB) and $\mathrm{H}_{2} \mathrm{O}_{2}$ (standard kit, Vector Laboratories) and enhanced with DAB enhancing solution (Vector Laboratories) after rinsing the sections with 0.05 M sodium bicarbonate, $\mathrm{pH} 9.6$ for $10 \mathrm{~min}$. Sections were then washed in tap water, counterstained with haematoxylin, dehydrated and mounted. Controls were performed using normal mouse serum or PBS instead of primary antibody. Immunohistochemistry was carried out in testis sections obtained from four animals per group. Reproducible results were obtained.

\section{Hormone assays}

Serum levels of LH and FSH were determined by double antibody radioimmunoassay (RIA) as previously described (Suescun et al. 1985). Results are expressed in terms of the reference preparations (rat LH-RP3 and 
FSH-RP2), supplied by the NIDKK, Bethesda, MD, USA. Sensitivity for the LH assay was $0 \cdot 024 \mathrm{ng} /$ tube and for FSH was 0·10 ng/tube.

Serum levels of testosterone were measured by RIA using testosterone $\left(1,2-\left[{ }^{3} \mathrm{H}\right](\mathrm{N})\right), 60 \mathrm{Ci} / \mathrm{mmol}$ from New England Nuclear (Boston, MA, USA) and a specific antibody from Immunotech Diagnostic (Montreal, Canada), as previously described and validated (Suescun et al. 1997). The sensitivity of the testosterone assay was $12.5 \mathrm{pg} / \mathrm{ml}$. Radioimmunoassay intra- and interassay coefficients of variation were less than $12 \%$.

\section{Inhibin measurement}

Inhibin was measured using a two-site ELISA specific for inhibin B as previously described (Groome et al. 1996). Briefly, before assay, $0 \cdot 5 \mathrm{vol} 6 \%$ aqueous SDS was added to all serum samples and standards and were heated for $3 \mathrm{~min}$ at $100{ }^{\circ} \mathrm{C}$. Samples were treated with freshly prepared $1 \%$ hydrogen peroxide solution for $30 \mathrm{~min}$ at room temperature. A sensitive amplified-enzyme assay (Ampak, DAKO Corp., Cambridgeshire, UK) was used to amplify the alkaline phosphatase activity. Recombinant human inhibin B was used as the standard. Activin A, activin B and follistatin showed less than $0 \cdot 1 \%$ cross-reaction in the inhibin B assay whereas inhibin A had less than $0.5 \%$ cross-reaction. The assay sensitivity was $15 \mathrm{pg} / \mathrm{ml}$. Intraand interassay coefficients of variation were less than $10 \%$. The human inhibin B assay has been previously validated for measurement of inhibin B in rat serum (Atanassova et al. 1999, Sharpe et al. 1999). In the present study, comparison of the slopes of the regression lines of transformed data for assay standards and serum samples indicated no significant departure from parallelism.

\section{Statistical analysis}

Data are expressed as means \pm S.E.M. Statistical analysis was performed on log-transformed data. One-way analysis of variance (ANOVA) followed by the Tukey-Kramer test was used for multiple comparisons. Correlation between variables was assessed by calculating the nonparametric Spearman's correlation coefficient (GraphPad Prism, 1994). $P<0 \cdot 05$ was considered significant.

\section{Results}

\section{Testis weight and histopathology}

Light microscopy showed that $60 \%$ of rats immunized with $\mathrm{TH}(\mathrm{E})$ developed EAO. Therefore, within the $\mathrm{E}$ group, subgroups of rats with (EAO) or without (ENL) testis lesions were observed. In animals from the EAO group both testes presented a similar degree of damage; only exceptionally was a different behaviour observed for each testis.

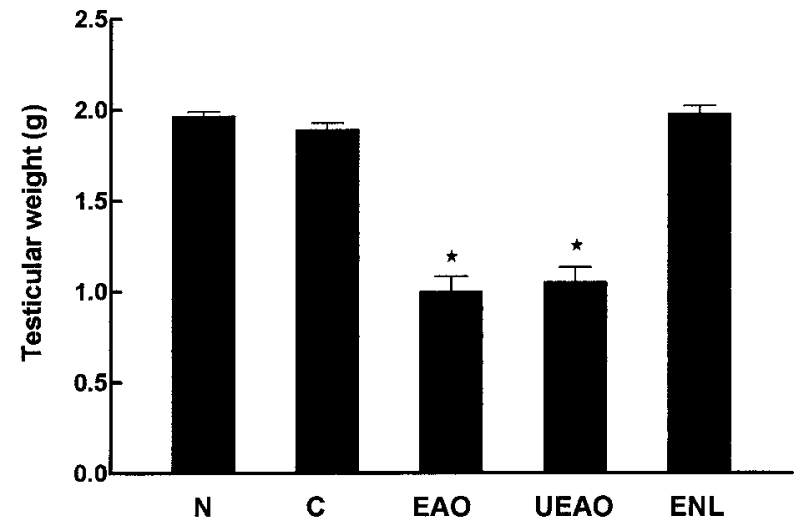

Figure 1 A significant decrease in testis weight was observed in rats from the experimental group with orchitis in both testes (EAO; $n=13$ ) or in one testis (UEAO; $n=5$ ). In the UEAO group, the contralateral testis weight was similar to that of the N, C and ENL $(n=6)$ groups. Data are expressed as means \pm S.E.M. ${ }^{*} P<0.05$ vs $N$, $\mathrm{C}$ and ENL groups.

Testicular weight from untreated $(\mathrm{N})$ and control $(\mathrm{C})$ rats was $1.97 \pm 0.03$ and $1.89 \pm 0.04 \mathrm{~g}$ respectively. A marked decrease $(60 \%)$ of testis weight was observed in rats from the EAO group when compared with rats from $\mathrm{C}$ or $\mathrm{N}$ groups (Fig. 1). Rats from the ENL group did not exhibit changes in testicular weight. In the few animals of the experimental group that presented orchitis unilaterally (UEAO), the testis with orchitis exhibited an identical decrease in weight to testes from the EAO group and the normal contralateral testis was of identical weight to testes from $\mathrm{N}$ or $\mathrm{C}$ groups.

As previously described (Doncel et al. 1989, Suescun et al. 1994), the testicular damage was characterized by large areas of aspermatogenic seminiferous tubules in which only spermatogonia and Sertoli cells remained attached to the tubular wall. An interstitial mononuclear cell infiltrate composed mainly of macrophages and lymphocytes intermingled with numerous Leydig cells was also observed. None of the rats from $\mathrm{N}$ and $\mathrm{C}$ groups revealed pathological alterations in the testis.

\section{Immunohistochemical results}

By immunohistochemical analysis, high expression of the inhibin $\alpha$-subunit was detected in Sertoli cells in testis sections from normal and control rats (Fig. 2A-C). An intense brown reaction product was present in the basal Sertoli cell cytoplasm. Other cells of the seminiferous tubules were negative. In contrast to $\mathrm{N}$ or $\mathrm{C}$ groups, rats from the EAO group (Fig. 2D-F) exhibited absence of inhibin $\alpha$-subunit expression in Sertoli cells from damaged tubules with severe germ cell sloughing. However, a faint positive reaction was detected in those partially damaged seminiferous tubules present in the testis of rats with orchitis. 

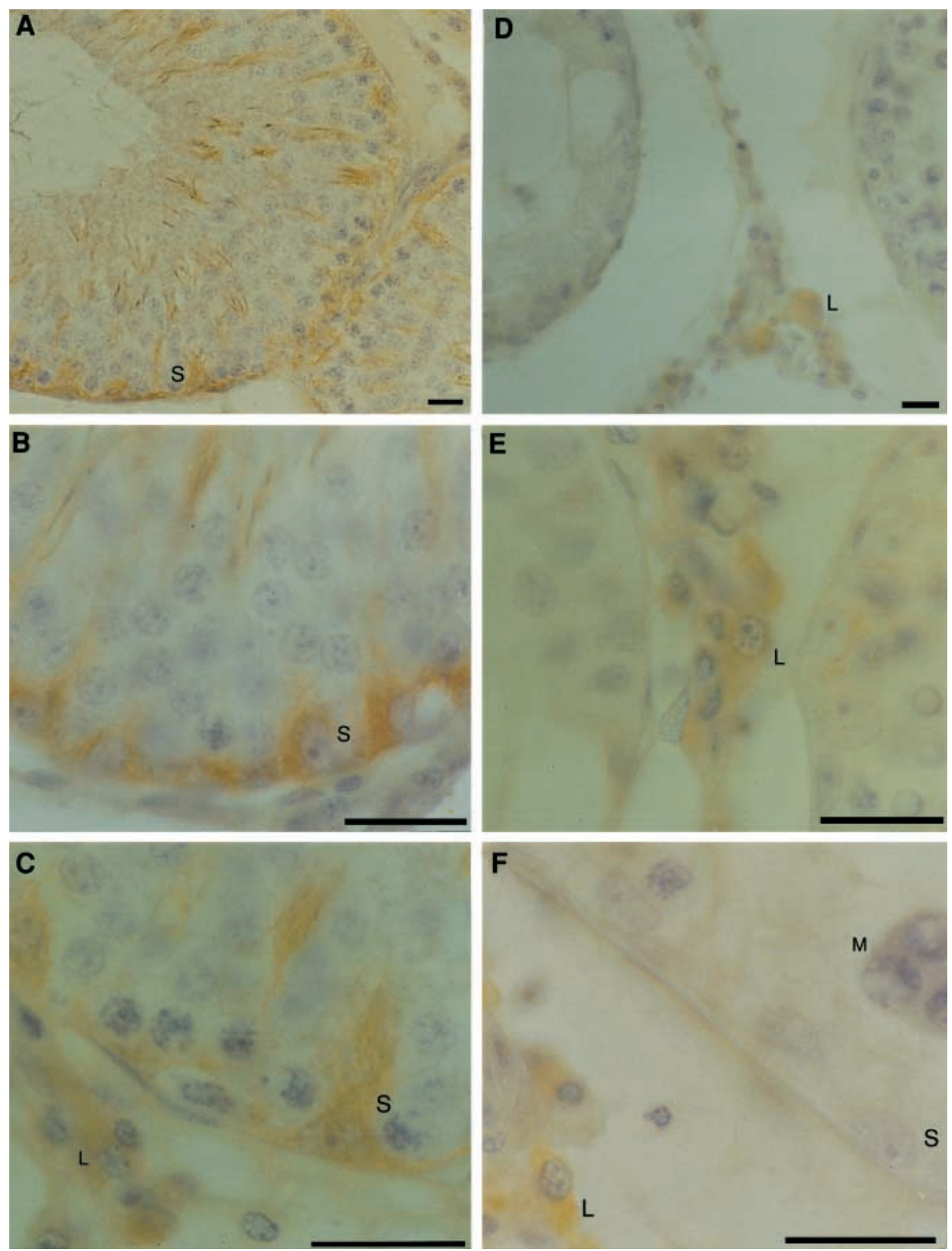

Figure 2 Immunohistochemical localization of inhibin $\alpha$-subunit in rat testis. Strong expression of the inhibin $\alpha$-subunit was observed in Sertoli cell cytoplasm (S) and in Leydig cells (L) in testis sections of control rats (A-C). Testis sections from rats with autoimmune orchitis (D-F) revealed absence of the inhibin $\alpha$-subunit in Sertoli cell cytoplasm in the severely damaged seminiferous epithelium. Strong expression of the $\alpha$-subunit was observed in Leydig cells from these rats. M, multinucleated cell. Magnifications: A and D, × 300; B and E, $\times 1000$ and C,F: $\times 1200$. Scale bar: $20 \mu \mathrm{m}$. 


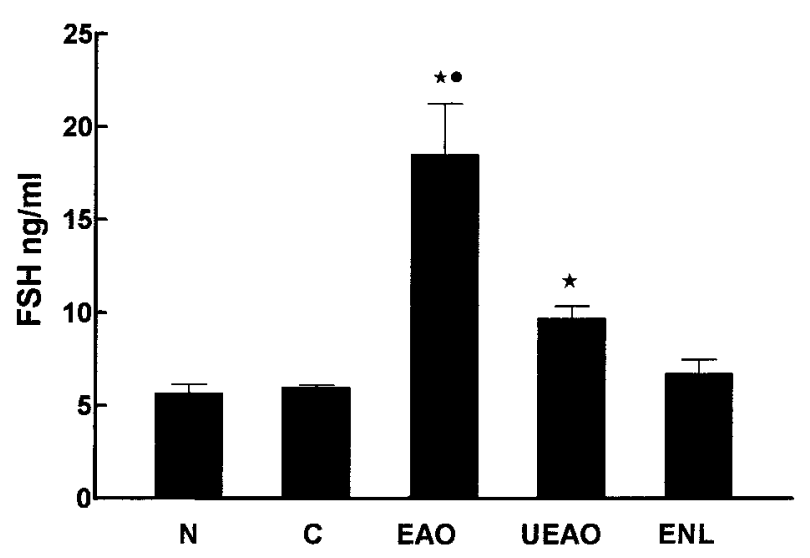

Figure 3 A 3-fold increase of serum FSH levels was observed in rats from the experimental group with orchitis (EAO; $n=13$ ). A lower but significant increase was observed in rats with unilateral orchitis (UEAO; $n=5)$. Rats from the experimental group without orchitis (ENL; $n=6)$ exhibited a profile similar to that of control $(C$, $n=6)$ or untreated normal rats $(N, n=6)$. Data are expressed as means \pm S.E.M. $\star P<0.05$ vs $\mathrm{N}, \mathrm{C}$ and $\mathrm{ENL}$ groups. $P<0.05$ vs UEAO group.

Leydig cells from all groups of rats studied expressed the inhibin $\alpha$-subunit, whereas no reaction was detected in other interstitial cells or blood vessels. In rats with orchitis, inhibin $\alpha$-subunit expression was observed in the cytoplasm of Leydig cells independently of the degree of testis damage. No staining was observed in testis sections incubated with PBS or normal mouse serum (data not shown).

\section{Hormone levels in serum}

Figure 3 shows serum FSH levels in experimental groups and controls. A 3-fold increase in FSH levels was observed in rats that developed EAO in comparison to rats from $\mathrm{N}$ and $\mathrm{C}$ groups. A lower but still significant increase (1.6-fold) of serum FSH levels was observed in rats from the UEAO group. No significant difference was found in serum FSH levels among N, C and ENL groups.

Rats with orchitis exhibited a 2-fold increase in serum $\mathrm{LH}$, when compared with $\mathrm{N}$ and $\mathrm{C}$ groups $(1 \cdot 8 \pm 0.31$ vs $0.8 \pm 0.27$ and $0.9 \pm 0.24 \mathrm{ng} / \mathrm{ml}$ respectively). No significant changes in serum testosterone levels were observed among N, C, EAO and ENL groups $(2 \cdot 2 \pm$ $0 \cdot 35 ; \quad 2 \cdot 3 \pm 0 \cdot 45 ; \quad 2 \cdot 0 \pm 0 \cdot 42$ and $2 \cdot 2 \pm 0 \cdot 31 \mathrm{ng} / \mathrm{ml}$ respectively).

\section{Serum inhibin B levels}

Figure 4 shows the results of a representative experiment. No significant difference was found in inhibin B serum levels in N, C and ENL groups. A significant decrease $(P<0 \cdot 05)$ in inhibin B levels was observed in rats with orchitis, whether EAO or UEAO rats, when compared

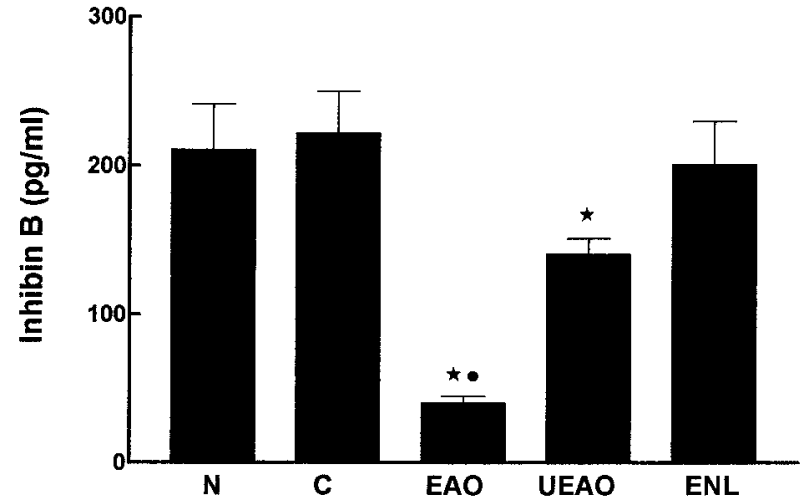

Figure 4 A marked decrease in serum inhibin B levels was observed in rats from the experimental group with orchitis (EAO; $n=13$ ). A less pronounced decrease was observed in rats with unilateral orchitis (UEAO; $n=5)$. Inhibin B levels of rats from the experimental group without orchitis $(E N L ; n=6)$ were similar to those observed in control $(C ; n=6)$ or untreated normal rats $(N$; $n=6)$. Data are expressed as means \pm S.E.M. $\star P<0.05$ vs $N, C$ and ENL groups. $P<0.05$ vs UEAO group.

with rats from N, C or ENL groups. The decrement in inhibin B levels observed in EAO animals was more marked $(80 \%)$ than that found in the UEAO group of rats $(35 \%)$. In some animals with orchitis (EAO), values of serum inhibin B were below the sensitivity of the method $(<15 \mathrm{pg} / \mathrm{ml})$.

A significant inverse correlation was found between inhibin B and FSH serum levels when control and all experimental groups (Fig. 5) or experimental groups alone were analysed $(r=-0.77, \quad P<0.0001$ and $r=-0.75$, $P<0 \cdot 0001$ respectively). No correlation was found between inhibin $\mathrm{B}, \mathrm{T}$ and $\mathrm{LH}$ levels. A significant direct correlation was found between inhibin B serum levels and testis weight $(r=0 \cdot 74, P<0 \cdot 0001)$.

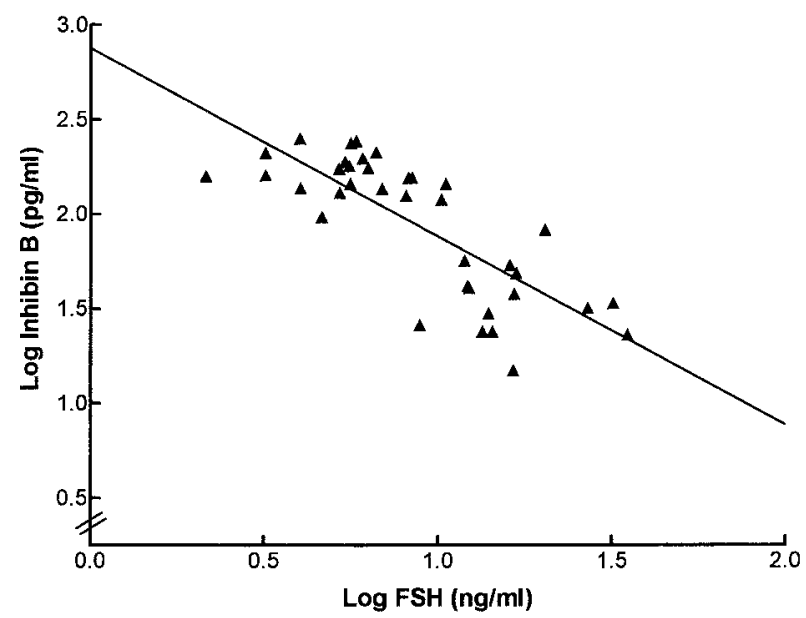

Figure 5 Correlation between log-transformed inhibin $\mathrm{B}$ and $\mathrm{FSH}$ serum levels determined in N, C, EAO, UEAO and ENL groups (Spearman correlation coefficient $r=-0 \cdot 77, P<0 \cdot 0001 ; n=36$ ). 


\section{Discussion}

As previously described (Doncel et al. 1989), experimental autoimmune orchitis induced in rats by active immunization with testicular homogenate and adjuvants is characterized by severe damage of the germinal epithelium and sloughing of germ cells except for spermatogonia and early spermatocytes. As shown by electron microscopy, Sertoli cells exhibit different degrees of cytoplasmic vacuolization. The aim of the present work was to use this experimental model to evaluate serum inhibin B levels as a functional marker of Sertoli cells and to determine the expression of the inhibin $\alpha$-subunit in testicular cells.

In the present study, as has previously been shown in men (Anawalt et al. 1996, Illingworth et al. 1996, Jensen et al. 1997), serum inhibin B and FSH levels were inversely correlated. Moreover, a strong correlation between serum inhibin B levels and testicular weight was observed. These findings are in accordance with those reported by Foppiani et al. (1999) and Pierik et al. (1998) who demonstrated a significant correlation between testicular volume and serum inhibin B levels in monkeys and humans.

Rats with severe damage of the germinal epithelium presented high serum FSH levels and very low or undetectable serum inhibin B levels when compared with rats from untreated or control groups. Interestingly, rats with unilateral testicular damage showed less marked alterations in FSH and inhibin B serum levels. These results show the close relationship that exists between inhibin B serum levels and the degree of seminiferous epithelium damage.

The involvement of germ cells in the regulation of Sertoli cell immunoreactive inhibin production (Allenby et al. 1991), early spermatids and pachythene spermatocytes (Pineau et al. 1990), has been previously reported in the rat. More recent studies carried out in testicular biopsies of infertile men have shown a high correlation between inhibin B levels and the degree of spermatogenic impairment. In agreement with the evidence obtained in experimental models, a positive influence of spermatids and pachytene spermatocytes in the regulation of inhibin $\mathrm{B}$ production has been proposed in men (Foresta et al. 1999).

In EAO, severe sloughing of germ cells (mainly spermatids and spermatocytes) occurs while Sertoli cells and spermatogonias remain attached to the basement membrane even in those rats with severely damaged seminiferous tubules. In this experimental model, a possible direct influence of cytokines on Sertoli cell inhibin production cannot be ruled out. However, a direct effect of locally produced cytokines on the decrease of inhibin B serum levels and inhibin $\alpha$-subunit expression appears to be unlikely since data from the literature show a pattern of cytokine-upregulated inhibin expression (Kubo et al. 1998, Li et al. 1998). The close relationship between the expression of inhibin $\alpha$-subunit and the degree of germ cell loss observed in Sertoli cells suggests that the spermatogenic damage is responsible for the dramatic decrease in Sertoli cell inhibin expression and low serum inhibin levels.

In rats with normal testicular histopathology ( $\mathrm{N}$ and $\mathrm{C}$ groups), Leydig and Sertoli cells were able to express the inhibin $\alpha$-subunit. However, damage to the germinal epithelium (in EAO rats) affected inhibin $\alpha$-subunit expression in Sertoli cells only. Leydig cells whether from control, untreated or experimental groups were able to express the inhibin $\alpha$-subunit in their cytoplasm. It has previously been demonstrated (Suescun et al. 1994, 1997, 2000) that in spite of the existence of severely damaged tubules, Leydig cells from EAO rats exhibit a normal morphology and ability to produce testosterone. Regarding Leydig cell capability to express inhibin subunits controversial observations have been reported. Koike \& Noumura (1993) showed that inhibin $\alpha$ and $\beta B$ subunits were present in rat fetal Leydig cells but the immunostaining was reduced in adult Leydig cells. In concordance with the results presented herein, a strong immunostaining in adult Leydig cells has been described by Nagata et al. (1998) in the stallion and by Bergh \& Cajander (1990) in human testis biopsies. On the other hand, our results show that normal expression of the inhibin $\alpha$-subunit in adult Leydig cells does not depend upon the presence of germ cells in the testis; these cells are able to express the inhibin $\alpha$-subunit in rats with orchitis. However, heterodimerization of inhibin subunits is unlikely to occur in these cells since inhibin B in serum was hardly detectable in these groups of animals.

The capacity to express inhibin $\alpha$-subunit was markedly impaired in Sertoli cells of the severely damaged seminiferous tubules. On the other hand, in those cells of the partially damaged seminiferous tubules present in the testis of rats with orchitis only a weak immunostaining was observed. These results show that germ cells may modulate expression of the inhibin $\alpha$-subunit in the Sertoli cell.

In different models of autoimmune orchitis, it has been shown that the target of the immunologic attack is the germ cell. Different cellular immunity mechanisms induce sloughing of the germinal epithelium with the result that seminiferous tubules contain only Sertoli cells and spermatogonia. The increase in FSH levels observed in rats with orchitis correlates with the inability of the Sertoli cell to secrete normal levels of inhibin B. Allenby et al. (1991) detected a significant increase of FSH levels in rats treated with methoxyacetic acid, which induces spermatocyte depletion. Moreover, Majundar et al. (1997) highlighted the importance of FSH-inhibin feedback loop in governing testicular function in primates. The dramatic decrease seen in the Sertoli cell capacity to either produce inhibin $\mathrm{B}$ or express the inhibin $\alpha$-subunit in rats experiencing a severe change in Sertoli cell microenvironment demonstrates the functional impairment of this cell. 
In summary, this study shows that in the adult rat, germ cells are needed not only for heterodimerization of the inhibin $\alpha$-subunit, but also for the expression of this subunit in the Sertoli cell itself. Leydig cells, on the other hand, seem to be unable to contribute to dimeric inhibin synthesis. Yet, the inhibin $\alpha$-subunit produced by these cells could well be used by the Sertoli cell to synthesize the dimeric form of inhibin.

\section{Acknowledgements}

This work was supported by grants from the Universidad Nacional de La Plata (X 201), the Universidad Nacional de Buenos Aires (TM 32), FONCyT (PICT 01790, PICT 98/05-03512) and the National Research Council of Argentina (CONICET) (PIP 0732). We thank the Instituto Nacional de Microbiología 'A. Malbrán' Div. Vacunas Bacterianas for the generous gift of Bordetella pertussis. MOS, LL, R SC and SC are established CONICET investigators.

\section{References}

Allenby G, Foster PMD \& Sharpe RM 1991 Evidence that secretion of immunoactive inhibin by seminiferous tubules from the adult rat testis is regulated by specific germ cell types: correlation between in vivo and in vitro studies. Endocrinology 128 467-476.

Anawalt BD, Bebb RA, Matsumoto AM, Groome NP, Illingworth PJ \& McNeilly AS 1996 Serum inhibin B levels reflect Sertoli cell function in normal men and men with testicular dysfunction. Journal of Clinical Endocrinology and Metabolism 81 3341-3345.

Anderson RA \& Sharpe RM 2000 Regulation of inhibin production in the human male and its clinical applications. International Journal of Andrology 23 136-144.

Andersson AM, Muller J \& Skakkebaek NE 1998 Different roles of prepubertal and postpubertal germ cells and Sertoli cells in the regulation of serum inhibin B levels. Journal of Clinical Endocrinology and Metabolism 82 889-896.

Atanassova N, McKinnell C, Walker M, Turner KJ, Fisher JS, Morley M, Millar MR, Groome NP \& Sharpe RM 1999 Permanent effects of neonatal estrogen exposure in rats on reproductive hormone levels, Sertoli cell number, and the efficiency of spermatogenesis in adulthood. Endocrinology 140 5364-5373.

Bergh A \& Cajander S 1990 Immunohistochemical localization of inhibin- $\alpha$ in the testes of normal men and in men with testicular disorders. International Journal of Andrology 13 463-469.

Bhasin S, Krummen A, Swerdloff RS, Morelos BS, Kim WH, diZerega GS, Ling N, Esch F, Shimasaki S \& Toppari J 1989 Stage dependent expression of inhibin $\alpha$ and $\beta \mathrm{B}$ subunits during the cycle of the rat seminiferous epithelium. Endocrinology 124 987-991.

Bicsack TA, Vale W, Vaughan J, Tucker EM, Cappel S \& Hsueh AJW 1987 Hormonal regulation of inhibin production by cultured Sertoli cells. Molecular Cellular Endocrinology 49 211-217.

Burger HG \& Robertson DM 1997 Inhibin in the male - progress at last. Endocrinology 138 1361-1362.

De Jong FH 1988 Inhibin. Physiological Reviews 68 550-607.

De Kretser DM \& McFarlane JR 1996 Inhibin in the male. Journal of Andrology 17 179-182.

Depuydt CE, Mahmoud AM, Dhooge WS, Schoonjans FA \& Comhaire FH 1999 Hormonal regulation of inhibin B secretion by immature rat Sertoli cells in vitro: possible use as a bioassay for estrogen detection. Journal of Andrology 20 54-62.
Doncel GF, Di Paola JA \& Lustig L 1989 Sequential study of the histopathology and cellular and humoral immune response during the development of an autoimmune orchitis in Wistar rats. American Journal of Reproductive Immunology 20 44-51.

Foppiani L, Schlatt S, Simoni M, Weinbauer GF, Hacker-Clom U \& Nieschlag E 1999 Inhibin B is a more sensitive marker of spermatogenetic damage than FSH in the irradiated non-human primate model. Journal of Endocrinology 162 393-400.

Foresta C, Bettella A, Rossato M, La Sala G, De Paoli M \& Plebari M 1999 Inhibin B plasma concentrations in oligozoospermic subjects before and after therapy with follicle stimulating hormone. Human Reproduction 14 906-912.

Groome NP, Hancock J, Betteridge A, Lawrence M \& Craven R 1990 Monoclonal and polyclonal antibodies reactive with the 1-32 amino terminal sequence of the alpha subunit of human $32 \mathrm{~K}$ inhibin. Hybridoma 9 31-35.

Groome NP, Illingworth PJ, O’Brien M, Cooke I, Ganesan TS, Baird DT \& McNeilly AS 1994 Detection of dimeric inhibin throughout the human menstrual cycle by two-site enzyme immunoassay. Clinical Endocrinology 40 717-723.

Groome NP, Illingworth PJ, O'Brien M, Pal R, Rodger FE, Mather JP \& McNeilly AS 1996 Measurement of dimeric inhibin B throughout the human menstrual cycle. Journal of Clinical Endocrinology and Metabolism 81 1401-1405.

Illingworth PJ, Groome NP, Byrd W, Rainey W E, McNeilly AS, Mather JP \& Bremner WJ 1996 Inhibin B: a likely candidate for the physiologically important form of inhibin in men. Journal of Clinical Endocrinology and Metabolism 81 1321-1325.

Jensen TK, Andersson AM, Hjollund NHI, Scheike T, Kolstad H, Giwercman A, Henriksen TB, Ernst E, Bonde JP, Olsen J, NcNeilly A, Groome NP \& Skakkebaek NE 1997 Inhibin B as a serum marker of spermatogenesis: correlation to differences in sperm concentration and follicle-stimulating hormone levels. A study of 349 Danish men. Journal of Clinical Endocrinology and Metabolism 82 4059-4063.

de Jong FH 1988 Inhibin. Physiological Reviews 68 555-607.

Klaij IA, van Pelt AMM, Timmerman MA, Black LJ, de Rooij DG \& de Jong FH 1994 Expression of inhibin subunit mRNA and inhibin levels in the testes of rats with stage-synchronized spermatogenesis. Journal of Endocrinology 141 131-141.

Koike S \& Noumura T 1993 Immunohistochemical expression of inhibin $\alpha$ subunit in the developing rat gonads. Zoology Science 10 449-454.

Kubo T, Shimasaki S, Kim H, Li D \& Erickson GF 1998 Activininduced inhibin $\alpha$-subunit production by rat granulosa cells requires endogenous insulin-like growth factor-I. Biology of Reproduction $\mathbf{5 8}$ 712-718.

Li D, Kubo T, Kim H, Shimasaki S \& Erickson GF 1998 Endogenous insulin-like growth factor-I is obligatory for stimulation of rat inhibin $\alpha$-subunit expression by follicle-stimulating hormone. Biology of Reproduction 58 219-225.

Mahi-Brown CA 1994 Autoimmune orchitis. Immunology and Allergy Clinics of North America 14 787-802.

Majundar SS, Winters SJ \& Plant TM 1997 A study of the relative roles of follicle-stimulating hormone and luteinizing hormone in the regulation of testicular inhibin secretion in the Rhesus monkey (Macaca mulatta). Endocrinology 138 1363-1373.

Merchenthaler I, Culler MD, Petrusz P \& Negro-Vilar A 1987 Immuno-cytochemical localization of inhibin in rat and human reproductive tissues. Molecular and Cellular Endocrinology $\mathbf{5 4}$ 239-243.

Nagata S, Tsunoda N, Nagamine N, Tanaka Y, Taniyama H, Nambo Y, Watanabe G \& Taya K 1998 Testicular inhibin in the stallion: cellular source and seasonal changes. Biology Reproduction 59 62-68.

Pierik FH, Vreeburg JTM, Stijnen T, de Jong FH \& Weber RFA 1998 Serum inhibin B as a marker of spermatogenesis. Journal of Clinical Endocrinology and Metabolism 83 3110-3114. 
Pineau C, Sharpe RM, Saunders PTK, Gerard N \& Jegou B 1990 Regulation of Sertoli cell inhibin production and of inhibin $\alpha$ subunit mRNA levels by specific germ cell types. Molecular and Cellular Endocrinology 72 13-22.

Rivier C, Cajander S, Vaughan J, Hsueh AJW \& Vale W 1988 Age dependent changes in physiological action, content and immunostaining of inhibin in male rats. Endocrinology 123 120-126.

Sharpe RM, Turner KJ, McKinnel C, Groome NP, Atanassova N, Millar MR, Buchanan DL \& Cooke PS 1999 Inhibin B in plasma of the male rat from birth to adulthood: effect of experimental manipulation of Sertoli cell number. Journal of Andrology 20 94-101.

Steinberger A \& Steinberger E 1976 Secretion of a FSH-inhibiting factor by cultured Sertoli cells. Endocrinology 99 918-921.

Suescun MO, Gonzalez SI, Chiauzzi VA \& Calandra RS 1985 Effects of induced hypoprolactinemia on testicular function during gonadal maturation in the rat. Journal of Andrology 6 77-82.
Suescun MO, Calandra RS \& Lustig L 1994 Alterations of testicular function after induced autoimmune orchitis in rats. Journal of Andrology 15 442-448.

Suescun MO, Calandra RS \& Lustig L 1997 Increased testosterone production in vitro by Leydig cells from rats with severe autoimmune orchitis. International Journal of Andrology 20 339-346.

Suescun MO, Calandra RS \& Lustig L 2000 Effect of testicular macrophage conditioned media from rats with autoimmune orchitis on Leydig cell function. American Journal of Reproductive Immunology 43 116-123.

Received in final form 27 February 2001

Accepted 8 March 2001 